\title{
Osteokines and the vasculature: a review of the in vitro effects of osteocalcin, fibroblast growth factor-23 and lipocalin-2
}

\author{
Sophie A Millar ${ }^{\text {Corresp., }}{ }^{1}$, Susan I Anderson ${ }^{1}$, Saoirse E O'Sullivan ${ }^{1}$ \\ ${ }^{1}$ Division of Graduate Entry Medicine and Medical Sciences, School of Medicine, Royal Derby Hospital, University of Nottingham, Derby, United Kingdom \\ Corresponding Author: Sophie A Millar \\ Email address: stxsamil@nottingham.ac.uk
}

Bone-derived factors that demonstrate extra-skeletal functions, also termed osteokines, are fast becoming a highly interesting and focused area of cross-disciplinary endocrine research. Osteocalcin (OCN), fibroblast growth factor-23 (FGF23) and lipocalin-2 (LCN-2), produced in bone, comprise an important endocrine system that is finely tuned with other organs to ensure homeostatic balance and health. This review aims to evaluate in vitro evidence of the direct involvement of these proteins in vascular cells and whether any causal roles in cardiovascular disease or inflammation can be supported. PubMed, Medline, Embase and Google Scholar were searched for relevant research articles investigating the exogenous addition of OCN, FGF23 or LCN-2 to vascular smooth muscle or endothelial cells. Overall, these osteokines are directly vasoactive across a range of human and animal vascular cells. Both OCN and FGF23 have anti-apoptotic properties and increase eNOS phosphorylation and nitric oxide production through Akt signalling in human endothelial cells. OCN improves intracellular insulin signalling and demonstrates protective effects against endoplasmic reticulum stress in murine and human endothelial cells. OCN may be involved in calcification but further research is warranted, while there is no evidence for a pro-calcific effect of FGF23 in vitro. FGF23 and LCN-2 increase proliferation in some cell types and increase and decrease reactive oxygen species generation, respectively. LCN-2 also has anti-apoptotic effects but may increase endoplasmic reticulum stress as well as have pro-inflammatory and pro-angiogenic properties in human vascular endothelial and smooth muscle cells. There is no strong evidence to support a pathological role of OCN or FGF23 in the vasculature based on these findings. In contrast, they may in fact support normal endothelial functioning, vascular homeostasis and vasodilation. No studies examined whether OCN or FGF23 may have a role in vascular inflammation. Limited studies with LCN-2 indicate a pro-inflammatory and possible pathological role in the vasculature but further mechanistic data is required. Overall, these ostenkines pose intriquing functions which should be investigated comprehensively to
Peer) reviewing PDF (2019:01:34734:2:0:NEW 7 May 2019) 
assess their relevance to cardiovascular disease and health in humans. 
1 Osteokines and the vasculature: a review of the in vitro effects of osteocalcin, 3 fibroblast growth factor-23 and lipocalin-2

Sophie A. Millar*, Susan I. Anderson and Saoirse E. O'Sullivan

* Corresponding author: Sophie Millar, stxsamil@nottingham.ac.uk

Word count: 4756

Short title: Osteokines and the vasculature 
11 Bone-derived factors that demonstrate extra-skeletal functions, also termed osteokines, are fast

12 becoming a highly interesting and focused area of cross-disciplinary endocrine research.

13 Osteocalcin (OCN), fibroblast growth factor-23 (FGF23) and lipocalin-2 (LCN-2), produced in

14 bone, comprise an important endocrine system that is finely tuned with other organs to ensure

15 homeostatic balance and health. This review aims to evaluate in vitro evidence of the direct

16 involvement of these proteins in vascular cells and whether any causal roles in cardiovascular

17 disease or inflammation can be supported. PubMed, Medline, Embase and Google Scholar were

18 searched for relevant research articles investigating the exogenous addition of OCN, FGF23 or

19 LCN-2 to vascular smooth muscle or endothelial cells. Overall, these osteokines are directly

20 vasoactive across a range of human and animal vascular cells. Both OCN and FGF23 have anti-

21 apoptotic properties and increase eNOS phosphorylation and nitric oxide production through Akt

22 signalling in human endothelial cells. OCN improves intracellular insulin signalling and

23 demonstrates protective effects against endoplasmic reticulum stress in murine and human

24 endothelial cells. OCN may be involved in calcification but further research is warranted, while

25 there is no evidence for a pro-calcific effect of FGF23 in vitro. FGF23 and LCN-2 increase

26 proliferation in some cell types and increase and decrease reactive oxygen species generation,

27 respectively. LCN-2 also has anti-apoptotic effects but may increase endoplasmic reticulum

28 stress as well as have pro-inflammatory and pro-angiogenic properties in human vascular

29 endothelial and smooth muscle cells. There is no strong evidence to support a pathological role

30 of OCN or FGF23 in the vasculature based on these findings. In contrast, they may in fact

31 support normal endothelial functioning, vascular homeostasis and vasodilation. No studies

32 examined whether OCN or FGF23 may have a role in vascular inflammation. Limited studies

33 with LCN-2 indicate a pro-inflammatory and possible pathological role in the vasculature but

34 further mechanistic data is required. Overall, these osteokines pose intriguing functions which

35 should be investigated comprehensively to assess their relevance to cardiovascular disease and

36 health in humans. 
37

38

39

40

41

42

43

44

45

46

47 48

49

50

51

52

53

54

55

56

57

58

59

60

61

62

63

64

65

66

\section{Introduction}

The role of the skeleton has greatly evolved from its premise of being a functional tissue providing primary protection, support, and haematopoietic maintenance. It is now recognised as an endocrine organ providing exciting opportunities for cross-disciplinary research. One candidate thread of enquiry is the skeleton's interaction with the vascular system. Bone is a highly vascularised tissue, which is important for growth, remodelling and repair. The endothelial cells lining blood vessels have an important influence on bone cells, often in a paracrine manner, establishing a 'bone-vascular axis' (Brandi and Collin-Osdoby, 2006). This traditionally viewed axis is also evolving to reflect that on the other hand, secreted, circulating bone-derived factors have direct effects on vascular cells themselves.

Recent research has demonstrated that three 'osteokines', namely osteocalcin (OCN), fibroblast growth factor-23 (FGF23) and lipocalin-2 (LCN-2), comprise an important endocrine system that is finely tuned with other organs to ensure homeostatic balance and health (Han et al., 2018). The endocrine functions of OCN have been extensively reviewed elsewhere (Ducy, 2011; Li et al., 2016; Karsenty, 2017; Han et al., 2018). Briefly, OCN has been reported to play an active role in the regulation of energy metabolism by improving glucose tolerance and insulin sensitivity and insulin production (Lee et al., 2007; Oury et al., 2011; Oury et al., 2013). Elsewhere, OCN ${ }^{-/-}$ male mice were observed to be poor breeders due to decreased testosterone production and thus has been linked to fertility (Oury et al., 2011). Interestingly, these $\mathrm{OCN}^{-/-}$mice also displayed behaviours associated with anxiety and depression and it was demonstrated that OCN can cross the blood-brain-barrier and enhance monoamine neurotransmitter synthesis, drawing a link between OCN and cognition (Oury et al., 2013). FGF23 is well characterised as the regulator of phosphate, parathyroid hormone (PTH), and vitamin D in the body which has been recently reviewed elsewhere (Richter and Faul, 2018). Briefly, in the kidneys, FGF23 increases phosphate excretion in urine, thus lowering serum concentrations. FGF23 is secreted by bone following stimulation by increased circulating vitamin D and extracellular phosphate. FGF23 in turn also supresses $1,25(\mathrm{OH})_{2} \mathrm{D}_{3}$ production. Thus, a regulatory feedback loop exists between the kidneys and bone through FGF23. In the kidneys, FGF23 also increases reabsorption of calcium and sodium (Andrukhova et al., 2014a; Andrukhova et al., 2014b), while in the parathyroid gland FGF23 supresses PTH production. The endocrine role of LCN-2 was an interesting discovery 


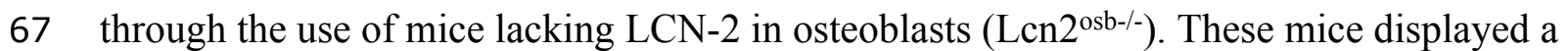

68 decrease in insulin sensitivity and secretion, through direct activity on pancreatic $\beta$-cells, and 69 decreased glucose tolerance (Mosialou et al., 2017). It has also been shown that LCN-2 crosses

70 the blood brain barrier and activates melanocortin 4 receptor-dependent appetite signalling in the 71 hypothalamus (Mosialou et al., 2017).

72 While these investigations have drawn evidence for the skeletal control of energy metabolism, 73 mineral homeostasis and much more, the effects of these hormones on the vasculature itself has 74 also gathered interest. Conflicting observational data exists between OCN, FGF23 and LCN-2 75 and markers of cardiovascular disease in humans (Dalal et al., 2011; Wang, 2012; Millar et al., 76 2017), which are discussed further within this review. In order to assess the relevance of these 77 osteokines to cardiovascular health, we aimed to provide an analysis of the direct effects of 78 OCN, FGF23 and LCN-2 on micro- and macro-vascular cells in vitro, and to highlight gaps in 79 the literature which need addressing, for use by clinicians and researchers.

80

81

82 83 84 85 86

87 88 89 90

91 92 93 94

\section{Survey Methodology}

1 To retrieve articles concerning the exogenous administration of OCN, FGF23 and LCN-2 to micro- or macro-vascular cells, the following search terms were used for database searching (PubMed, Embase, Medline, Google Scholar): fibroblast growth factor 23, bone gammacarboxyglutamic acid protein, osteocalcin, lipocalin 2, LCN-2, neutrophil gelatinase-associated lipocalin, NGAL, vascular cell, vascular endothelial cell, and vascular smooth muscle cell. Additionally, the reference lists of relevant review articles and included articles were handsearched for further studies. Searches were carried out up until 20/09/2018. Retrieved articles were included if they described the exogenous addition of OCN, FGF23 or LCN-2 to vascular cells in vitro i.e. studies that examined the endogenous over-expression of these osteokines were excluded, as the results would not be deemed to be bone-derived. Similarly, passive reporting of osteokines e.g. expression studies, were not evaluated as this approach excludes the possibility of bone-derived effects and we were interested in clarifying any direct, causal effects of 'circulating' osteokines. Only peer-reviewed, full-text articles were included, not conference abstracts or articles not in English. 
96 Osteocalcin (OCN) has been pioneered as a skeletal hormone for over a decade now, solidifying 97 a role in influencing energy metabolism (Lee et al., 2007). The mature OCN is a 46 or 49 amino 98 acid protein in mice and humans respectively, predominantly produced by osteoblasts, and is the 99 most abundant, non-collagenous protein in the mineralised matrix of bone (Hauschka et al., 1975; Price et al., 1976; Celeste et al., 1986; Hauschka et al., 1989). Due to the presence of 3

101 102

103

104

105

106

107

108

109

110

111

112

113

114

115

116

117

118

119

120

121

122

123

124 glutamic acid residues which may undergo carboxylation, $\mathrm{OCN}$ is present in various forms. These include undercarboxylated OCN with 1 or 2 glutamic acid residues (unOCN), carboxylated OCN with no glutamic acid residues (cOCN), or uncarboxylated OCN (ucOCN) with 3 glutamic acid residues. Carboxylation induces a conformational change resulting in a high affinity for calcium ions. Thus, OCN is also referred to as bone $\gamma$-carboxyglutamic acidcontaining protein (BGLAP) and binds to hydroxyapatite crystal lattices present in bone extracellular matrix (Hauschka et al., 1989). unOCN and ucOCN have less affinity to hydroxyapatite and are more readily released into the circulation. These forms have been the most widely studied and are considered to be the 'active' forms of OCN (Plantalech et al., 1991; Cairns and Price, 1994; Ferron et al., 2010). Despite the abundance of OCN in bone, its exact role and function in bone reformation has not been clearly defined. However, serum concentrations of OCN may be used as a marker of bone turnover as it is widely accepted to be released from mature osteoblasts during bone formation (Bellows et al., 1999).

\section{Circulating concentrations of OCN}

There is currently no consensus on which OCN fragments to measure, and there are no international or national standards (Lee et al., 2000). Total OCN concentrations have been reported by Hannemann et al. by age and gender (Hannemann et al., 2013). However, reported serum ucOCN and unOCN concentrations in studies have largely varied, for example between 0.1 and $0.3 \mathrm{ng} / \mathrm{mL}$, and up to $21.4 \mathrm{ng} / \mathrm{mL}$ or $33.0 \mathrm{ng} / \mathrm{mL}$ (Plantalech et al., 1991; Binkley et al., 2000; Iki et al., 2012). OCN concentrations increase with age but can be reduced by supplementation with vitamin K (Knapen et al., 1989; Plantalech et al., 1991; Knapen et al., 1993). cOCN concentrations have also not been defined and have been reported to lie around 8$10 \mathrm{ng} / \mathrm{mL}$ or higher e.g. $23.9 \mathrm{ng} / \mathrm{mL}$ (Luukinen et al., 2000; Tsukamoto et al., 2000; Sugiyama and Kawai, 2001). To add to the complexity of measuring circulating OCN, only $25 \%$ is found 
125 intact, and further additional forms are also present including N-terminal, mid-region, mid-

126 region-C-terminal, and C-terminal fragments released by proteolytic cleavage (Garnero et al., 127 1994).

\section{OCN and the vasculature}

129 A number of cross-sectional studies have highlighted associations between OCN concentrations

130 and atherosclerosis and calcification, however, we found that a meta-analysis of these data could 131 not provide a conclusive role as study results were mixed and conflicting with a number of 132 limitations (Millar et al., 2017). Analysing the direct interaction of OCN and its forms with 133 vascular cells may elucidate whether OCN is a mediator or marker of vascular calcification or 134 atherosclerosis, and whether it functions to affect vascular cells independently of its previously 135 noted metabolic influences. Cross-sectional evidence also exists regarding a role for OCN in 136 inflammation, with some population data highlighting an inverse association between OCN 137 concentrations and systemic inflammatory makers such as C-reactive protein and interleukin-6 138 (Pittas et al., 2009; Chen et al., 2013; Lucey et al., 2013; Sarkar and Choudhury, 2013; Liao et 139 al., 2015). A recent summary of in vivo ucOCN treatments in mice and rats concluded that $140 \mathrm{ucOCN}$ protects vascular function and protects against markers that are commonly associated 141 with the development of atherosclerosis (Tacey et al., 2018). However, these findings are 142 concomitant with improved metabolic status, and as such, the establishment of direct effects of $143 \mathrm{OCN}$ and its forms on vascular cells needs confirmation. The following section aims to 144 summarise in vitro investigations on the exogenous addition of OCN to vascular endothelial or 145 smooth muscle cells (see Table 1).

146

147 148 149 150 151 152 153 154

\section{Osteocalcin in human and animal cells}

Jung et al. (2013) reported an increase in Akt and eNOS phosphorylation and nitric oxide (NO) production in a PI3-kinase dependent manner in human aortic endothelial cells (HAECs) when treated with ucOCN (0.3-30.0 ng/mL) (Jung et al., 2013). They also demonstrated an antiapoptotic effect of ucOCN, in which $30 \mathrm{ng} / \mathrm{mL}$ pre-treatment prevented linoleic acid induced apoptosis, also via the PI3K/Akt pathway. Similarly, another study showed an increase in eNOS phosphorylation in HAECs after 30 minutes incubation with ucOCN (25 and $100 \mathrm{ng} / \mathrm{mL})$ (Kondo et al., 2016). Interestingly, eNOS phosphorylation however was not affected by the same concentrations of cOCN (Kondo et al., 2016). Total OCN ( $>30.0 \mathrm{ng} / \mathrm{mL}$ ) was reported to 
155 increase Akt and eNOS phosphorylation in human umbilical vein endothelial cells (HUVECs) in 156 a time- and dose-dependent manner (Dou et al., 2014). Another study in HUVECs, in which

157 insulin resistance was induced by tunicamycin, ucOCN $(5 \mathrm{ng} / \mathrm{mL})$ improved insulin signal

158 transduction via PI3K/Akt/NF-אB pathways (Guo et al., 2017). Similarly, mouse vascular 159 endothelial cells (VECs) and smooth muscle cells (VSMCs) were treated with $5 \mathrm{ng} / \mathrm{mL} \mathrm{ucOCN}$ 160 which protected against tunicamycin induced endoplasmic reticulum (ER) stress and autophagy, 161 and improved insulin signalling in an Akt/mTOR/NF-кB pathway (Zhou et al., 2013).

162 Idelevich et al. importantly identified that OCN may indeed be an active player in vascular 163 calcification, and not merely a product of differentiated VSMCs to an osteogenic phenotype 164 (Idelevich et al., 2011). They demonstrated that overexpression of OCN stimulated glucose 165 utilisation through activation of HIF-1 $\alpha$ and promoted mineralisation and osteogenic 166 differentiation in mouse vascular smooth muscle cells (MOVAS). Silencing of OCN RNA 167 suppressed these effects. However, this does not distinguish an effect of osteoblast derived, 168 circulating OCN, but rather locally produced effects from overexpression. However, when total 169 OCN was exogenously added to wild-type MOVAS, OCN was shown to be a glucose 170 metabolism-modulating factor, through HIF-1 $\alpha$. No investigations have been conducted in 171 human vascular smooth muscle cells to date. Ultimately, further investigation is needed into the 172 potential direct influence of OCN on vascular calcification.

173 Overall, these studies support a hypothesis that OCN, ucOCN particularly, is directly vasoactive, 174 and can increase nitric oxide via the PI3K/Akt/eNOS signalling pathway, which ultimately 175 influences vasodilation. Additionally, further atheroprotective effects are demonstrated through 176 protecting against high fatty acid induced apoptosis and improving insulin signalling. Although 177 Jung et al. who used relatively physiological concentrations demonstrated a potential positive 178 role of ucOCN in HAECs (increasing NO production and thus improving endothelial function), 179 Idelevich et al. in contrast propose that OCN stimulates mineralisation and differentiation of 180 mice VSMCs. It remains to be seen whether these disparities are due to differing effects of forms 181 of OCN within different cell types and species, incubation timings or origin and concentrations 182 of OCN, and whether OCN displays various functionalities that cannot be simply categorised 183 into a good or bad role within the vasculature. The direct role of OCN within inflammation in the 184 vasculature has also not been investigated. These limited studies and abundant questions signal 
185 there is need to clarify the role of physiologically relevant concentrations of OCN in human

186 vascular cells. Moreover, the effects of both unOCN and cOCN, and potentially other OCN

187 fragments, must be distinguished and deserves greater focus. Particularly as unOCN is more

188 likely to be in circulation than fully non carboxylated OCN.

189 Fibroblast growth factor 23

190 Osteocytes, which are the most abundant bone cell type, are the predominant secretors along

191 with osteoblasts of fibroblast growth factor 23 (FGF23). FGF23 is the first described bone

192 hormone and original phosphotonin (Bonewald and Wacker, 2013; Bonnet, 2017). FGF23 is a

193251 amino acid protein in humans regulated at gene and protein level (Bonewald and Wacker,

194 2013). FGF23 is proteolytically cleaved upon secretion. Susceptibility to cleavage is reduced by

195 O-glycosylation by polypeptide N-acetylgalactosaminyltransferase 3 which allows more intact,

196 biologically active FGF23 to be secreted (approximately $32 \mathrm{kDa}$ ) (Erben, 2017). On the other

197 hand, phosphorylation of FGF23 promotes cleavage resulting in C-terminus and N-terminus

198 fragments, whose biological activity is unclear. Soluble or transmembrane $\alpha$-Klotho is believed

199 to be the cofactor required to allow for activation of FGF receptors by FGF23, though in some

200 tissues FGF23 can have klotho independent effects (Urakawa et al., 2006; Chen et al., 2018;

201 Richter and Faul, 2018). Within bone, the actions of locally produced FGF23 by osteocytes, as

202 well as osteoblasts, have not been fully elucidated. Within mice, FGF23 may be a regulator of

203 bone mineralisation in an autocrine/paracrine manner through inhibiting tissue non-specific

204 alkaline phosphatase (TNAP). This results in increased pyrophosphate concentrations, likely in a

205 klotho independent manner due to low concentrations of klotho within bone (Murali et al., 2016;

206 Erben, 2017).

207 Circulating concentrations of FGF23

208 FGF23 reaches its target organs through the circulation. Similar to OCN, there is complexity in 209 measuring FGF23 as there are various presenting forms. Intact FGF23 (iFGF23) is the most

210 commonly used measurement, while C-terminus FGF23 (cFGF23) assays can also be used which

211 measure both iFGF23 and cFGF23 (Smith, 2014). iFGF23 is also subject to ex vivo degradation

212 and exhibits diurnal variation, while cFGF2 concentrations can be influenced by iron levels,

213 fibrous dysplasia or familial tumoral calcinosis (Wolf et al., 2013; Smith, 2014). In adults, mean

$214 \mathrm{cFGF} 23$ has been reported at $49.0 \mathrm{RU} / \mathrm{mL}$, and iFGF23 at $26.1 \mathrm{pg} / \mathrm{mL}$, but high intra-individual

Peer] reviewing PDF | (2019:01:34734:2:0:NEW 7 May 2019) 
215 variability exists which limits its application as a diagnostic or management tool (Smith et al., 216 2012). Paediatric reference values have been published for cFGF23 only (22.0 - 91.0 RU/ml)

217 (Fischer et al., 2012). In patients with chronic kidney disease (CKD), circulating FGF23 is 218 increased with decreasing renal function, and can reach up to 1000 times higher than normal

219 levels (Larsson et al., 2003; Fliser et al., 2007; Gutierrez et al., 2008; Isakova et al., 2011).

\section{FGF23 and the vasculature}

221 A number of epidemiological studies in humans have reported associations between increased

222 circulating FGF23 concentrations and vascular dysfunction (Mirza et al., 2009a), vascular

223 calcification (Roos et al., 2008; Desjardins et al., 2012) and increased risk of cardiovascular

224 disease (Dalal et al., 2011). FGF23 concentrations have been positively correlated with left

225 ventricular hypertrophy $(\mathrm{LVH})$, which is particularly apparent in CKD patient cohorts (Hsu and

226 Wu, 2009; Mirza et al., 2009b). Other studies have not shown an association between FGF23 and 227 vascular calcification or atherosclerotic events in CKD patients (Seiler et al., 2014; Sarmento-

228 Dias et al., 2016). A recent meta-analysis of prospective studies concluded that the relationship 229 between FGF23 and cardiovascular disease risk is unlikely to be causal (Marthi et al., 2018). An 230 established line of thought is that increased FGF23 may follow, as opposed to initiate, 231 cardiovascular dysregulation (Stohr et al., 2018). It is likely that negative effects of high FGF23 232 are due to dysregulated phosphate metabolism. However, the research surrounding FGF23 is 233 constantly evolving as the investigation into $\alpha$-klotho dependent and independent effects 234 continues, as well as the potential effects of locally produced FGF23 within the cardiovascular 235 system. FGF23 levels have also been associated with inflammation in CKD patients and in other 236 inflammatory disorders (David et al., 2017). The following section reviews the direct effects of 237 exogenously added FGF23 on vascular cells in order to provide insight into the possible bone238 derived effects as FGF23 travels through the circulation to reach its canonical target organs (see 239 Table 2).

\section{FGF23 in human and animal cells}

241 In recent years, literature has emerged directed at elucidating the direct effects of FGF23 in the 242 vasculature. In human aortic smooth muscle cells (HASMCs), $10 \mathrm{ng} / \mathrm{mL}$ of exogenous FGF23 243 has been shown to increase phosphorylation of ERK (extracellular signal-regulated kinase) after

24410 minutes in serum-starved cells, which in turn increased production of Early Growth Response 
245 Protein-1 (EGR-1) (Nakahara et al., 2016). Also in human VSMCs, $10 \mathrm{ng} / \mathrm{mL}$ of FGF23

246 increased hydrogen peroxide production and did not induce nitric oxide (NO) production on its 247 own, however when soluble klotho and phosphate were also added, NO was increased (Six et al., 248 2014). In the context of calcification, $5 \mathrm{ng} / \mathrm{mL}$ of FGF23 increased HASMC proliferation after 24924 hours in cells cultured in calcification media, and increased phosphorylation of ERK and 250 AKT in a klotho-dependent manner (Lim et al., 2012). 24 hour pre-treatment with FGF23 and 251 calcitriol, followed by culture in calcification media, deterred calcification in HASMCs in a 252 klotho dependent fashion, but this effect was not seen with FGF23 alone (without calcitriol) 253 (Lim et al., 2012). Scialla et al. (2013) did not find any evidence for a pro-calcific effect of 254 FGF23 in HASMCs (1-50 ng/mL), nor an increase in ERK phosphorylation (Scialla et al., 2013). 255 Reflecting results shown in human VSMCs, FGF23 alone (10 and $50 \mathrm{ng} / \mathrm{mL}$ ) reduced calcium 256 deposition in the context of calcification in murine VSMCs through ERK signalling (Zhu et al., 257 2013), whereas in bovine VSMCs 0.2-2.0 ng/mL FGF23 did not modify calcification (Lindberg 258 et al., 2013). In a study with murine VSMCs no effect of FGF23 on calcification was observed 259 (1-50 ng/mL) (Scialla et al., 2013).

260 In microvascular endothelial cells, FGF23 did not increase ERK phosphorylation, nor in human 261 umbilical vein endothelial cells did FGF23 increase hydrogen peroxide production (Six et al., 262 2014; Verkaik et al., 2018). In HAECs, FGF23 (50 and $100 \mathrm{ng} / \mathrm{mL}$ ) increased proliferation after 26348 hours, while $10 \mathrm{ng} / \mathrm{mL}$ stimulated phosphorylated eNOS and NO production (Chung et al., 264 2017). These results were no longer observed following $\alpha$-klotho knockdown and could not be 265 rescued by addition of soluble klotho, indicating that these effects were dependent on localised 266 endogenous $\alpha$-klotho production in HAECs. Interestingly, no increase in proliferation, nor eNOS 267 phosphorylation or NO production were observed in the same conditions in human brain 268 microvascular cells (Chung et al., 2017). In coronary artery endothelial cells (HCAECs), Richter 269 et al. (2016) demonstrated that $10 \mathrm{ng} / \mathrm{mL}$ of FGF23 increased expression of the FGF receptor-1, 270 increased eNOS phosphorylation and NO in an Akt-dependent manner, increased ROS 271 production and ROS detoxification, and additionally increased secretion of soluble klotho via 272 upregulation of ADAM17 (Richter et al., 2016). In blocking klotho, the authors further 273 demonstrated an upregulation of ROS and decrease in NO. In murine aortic endothelial cells, 9 $274 \mathrm{ng} / \mathrm{mL}$ FGF23 significantly increased superoxide levels (Silswal et al., 2014). 
275 These collated results begin to untie whether FGF23 may have any causal effects within the

276 context of cardiovascular pathologies. A few conclusions can be made including: FGF23 initiates

277 direct effects on vascular cells including SMCs and ECs but actions may be tissue specific;

278 FGF23 appears to increase eNOS phosphorylation and NO production likely in an Akt dependent

279 manner, and predominantly in a klotho-dependent manner (perhaps restricted to locally produced

280 klotho and not systemic circulating klotho); however, FGF23 also appears to increase ROS and

281 oxidative stress, which is counteracted by klotho; within calcification models, FGF23 increased

282 proliferation of SMCs, but does not appear to increase calcification and indeed may be anti-

283 calcific. Bringing these results together paints a conflicting but potential positive role of FGF23

284 in vascular function. The results presented encourages the hypothesis that the associations and

285 correlations between FGF23 and CVD are most likely due to deleterious effects of altered

286 phosphate and mineral metabolism and indeed that FGF23 levels likely follow, as oppose to

287 direct, cardiovascular disturbances. It is a complex area, with further discrepancies such as

288 variable physiological and disease states, deficiency of klotho, origin of secretion of FGF23 and

289 klotho, and many more factors leaving the role of FGF23 in the vasculature not a simple question

290 to be answered. Further confirmative examinations are necessary and investigations into whether

291 N- and C-terminal fragments of FGF23 are additionally biologically active and if so, how they

292 differ from intact FGF23. Interestingly, any direct pro- or anti-inflammatory properties of FGF23

293 on vascular cells have not yet been explored despite cumulating evidence in other tissues for a

294 role of FGF23 in inflammation (David et al., 2017).

295

296

297

298

299

300

301

302

303

304

\section{Lipocalin-2}

Lipocalin-2 (LCN-2), also referred to as neutrophil gelatinase-associated lipocalin (NGAL) or $24 \mathrm{p} 3$, is the most recently identified osteokine. However, it is debatable whether LCN-2 can be strictly described as such as it is secreted by a wide variety of cell types, and has indeed been more widely described as an adipokine to date. Despite this, it has recently been reported to be produced in bone ten-fold more than in white fat, at least in mice, and it remains to be reported whether this is also the case in humans (Mosialou et al., 2017). As such, LCN-2 is predominantly an osteoblast and adipocyte derived $25 \mathrm{kDa}$ secreted glycoprotein which acts as a lipid chaperone positioning itself as a key pro-inflammatory link between obesity and associated metabolic disorders and vascular disease (Kjeldsen et al., 1993; Wang, 2012). It exists in vivo as a

Peer] reviewing PDF | (2019:01:34734:2:0:NEW 7 May 2019) 
305 monomer, homodimer, or heterodimer by forming a complex with matrix metalloproteinase-9 306 (MMP-9) which stabilizes MMP-9 by preventing autodegradation (Kjeldsen et al., 1993; Yan et 307 al., 2001; Chakraborty et al., 2012). LCN-2 has been identified to mediate an innate immune 308 response to bacteria by sequestering iron and induces apoptosis in many cell types (Devireddy et 309 al., 2001; Flo et al., 2004).

\section{Circulating concentrations of LCN-2}

311 LCN-2 is increased in obese individuals, which is presumed derived from increased adipose 312 tissue and also increased expression from the liver, but may also be due to changes in skeletal 313 homeostasis which is also altered in obesity (Wang et al., 2007; Luo et al., 2016). It has been 314 suggested that LCN-2 can be used as a biomarker for early renal injury (Mishra et al., 2004; 315 Mishra et al., 2005). For example, in children undergoing surgery, those who did not 316 subsequently develop acute renal injury had LCN-2 serum concentrations $<50 \mathrm{ng} / \mathrm{mL}$, but $50 \%$ 317 of those who did develop acute renal injury has concentrations $>50 \mathrm{ng} / \mathrm{mL}$ (Mishra et al., 2005). 318 In a study of 1203 Chinese obese and non-obese men, LCN-2 serum concentrations were in the 319 range $29.3-53.5 \mathrm{ng} / \mathrm{mL}$ (Luo et al., 2016). In patients with Type 2 Diabetes, serum levels were 320 significantly higher in those with subclinical atherosclerosis than those without $(112.9 \mathrm{ng} / \mathrm{mL}$ 321 versus $77.2 \mathrm{ng} / \mathrm{mL}$ ) (Xiao et al., 2013). LCN-2 serum concentrations are also higher in patients 322 with metabolic syndrome compared to those without $(83.2 \mathrm{ng} / \mathrm{mL}$ versus $67.5 \mathrm{ng} / \mathrm{mL}$ ) (Wang et 323 al., 2007).

\section{Lipocalcin-2 and the vasculature}

325 LCN-2 is a novel, debatable osteokine. Examining its effects on vascular cells when originating 326 from osteoblasts presents a difficult task, requiring for example tissue specific knock-down 327 studies. Further validation to characterise LCN-2 as an osteokine with more convincing human 328 data is primarily needed. As LCN-2 has been associated with a stage-dependent contribution to 329 atherosclerosis, promoting lipotoxicity within the vasculature in obese states, and causing 330 endothelial dysfunction and cardiovascular complications, it is important to establish whether 331 bone-derived LCN-2 is a key mediator that could be therapeutically targeted (Wang, 2012; 332 Amersfoort et al., 2018). LCN-2 is also proposed as a sensitive marker for cardio-renal disease in 333 patients with acute heart failure (Mishra et al., 2005; Alvelos et al., 2011). 
334 Most studies to date have focused on observational and epidemiological data on the involvement 335 of LCN-2 in obesity and diabetic associated vascular complications. It is currently unfounded to 336 speculate whether these effects are influenced by bone derived LCN-2. The limited

337 investigations on the direct exogenous addition of this interesting protein in vascular cells are 338 summarised below and in Table 3.

339

340

341

342

343

344

345

346

347

348

349

350

351

352

353

354

355

356

357

358

359

360

361

362

\section{LCN-2 in human and animal cells}

Wang and colleagues, interested in investigating pulmonary hypertension, demonstrated that in human pulmonary artery smooth muscle cells (HPASMCs), LCN-2 at 10 and $20 \mathrm{ng} / \mathrm{mL}$ increased proliferation after $24 \mathrm{hrs}$ (Wang et al., 2015). LCN-2 promoted the activity of the PI3K pathway by increasing Akt phosphorylation (3-30 ng/mL) after $24 \mathrm{hrs}$, which was abrogated by an Akt inhibitor (Wang et al., 2015). This inhibitor also partly prevented the LCN-2 induced increase in proliferation. Interestingly, this group previously showed in the same cell type that 10 ng/mL LCN-2 decreased serum deprivation induced apoptosis after $24 \mathrm{hrs}$ compared to control, and furthermore decreased the susceptibility of HPASMCs to $\mathrm{H}_{2} \mathrm{O}_{2}$ induced apoptosis (Wang et al., 2014). They further showed that LCN-2 was decreasing the cleavage and activity of caspase3, and decreasing expression of Bax, an important pro-apoptotic factor. Finally, they confirmed LCN-2 (3-100 ng/mL for $24 \mathrm{hrs)} \mathrm{increased} \mathrm{the} \mathrm{expression} \mathrm{of} \mathrm{superoxide} \mathrm{dismutase} 1$ and 2 (SOD1 and SOD2) dose-dependently and $10 \mathrm{ng} / \mathrm{mL}$ decreased intracellular reactive oxygen species (ROS) both with and without $\mathrm{H}_{2} \mathrm{O}_{2}$. This group went on to show that LCN-2 $(10 \mathrm{ng} / \mathrm{mL})$ in fact promoted endoplasmic reticulum (ER) stress and proliferation within HPASMCs via increased intracellular iron levels (Wang et al., 2017).

HUVECs and human coronary artery smooth muscle cells (HCASMCs) treated with LCN-2 (200 $\mathrm{ng} / \mathrm{mL}, 500 \mathrm{ng} / \mathrm{mL}$ or $1 \mu \mathrm{g} / \mathrm{mL}$ ) significantly increased secretion of inflammatory markers interleukin-8 (IL-8), IL-6 and monocyte chemoattractant protein-1 (MCP-1) in a dose-dependent manner (Eilenberg et al., 2016). Within the central nervous system, LCN-2 $(10 \mu \mathrm{g} / \mathrm{mL})$ was shown to increase mRNA expression of C-X-C motif chemokine 10 in mice brain microvascular endothelial cells (BMVECs), providing preliminary evidence that LCN-2 may act as a chemoattractant inducer and promote neuroinflammation (Lee et al., 2011). In another study in rat brain endothelial cells, LCN-2 $(0.5-2 \mu \mathrm{g} / \mathrm{mL})$ enhanced angiogenesis, shown through 
363 Matrigel tube formation and scratch migration, via iron and ROS related pathways (Wu et al., 364 2015).

365 Despite the clinical associations between LCN-2 and vascular disturbances, the mechanisms at a 366 cellular level by physiological concentrations of exogenous LCN-2 have been largely

367 disregarded and research is warranted. The investigations to date have largely focused on LCN-2 368 in the context of pulmonary hypertension and the use of HPASMCs. Within this cell type LCN-2 369 is shown to have anti-apoptotic and pro-proliferative effects, while also decreasing ROS but 370 promoting ER stress. It has also been demonstrated that LCN-2 may be pro-inflammatory in a 371 number of cells types, which may be viewed as beneficial in the acute inflammatory response

372 (Castellheim et al., 2009). Concentrations of LCN-2 used in the studies reviewed have been quite 373 varied $(3 \mathrm{ng} / \mathrm{mL}-10 \mu \mathrm{g} / \mathrm{mL})$. It is clear there is a large scope of research yet to be completed in 374 this area to inform researchers and clinicians about any potential contribution of LCN-2 in 375 vascular physiological and pathophysiology.

376

377

378

379

380

381

382

383

384

385

386

387

388

389

390

391

392

\section{Summary and conclusions}

The effects of bone-derived factors on systemic health is an emerging, interesting branch of endocrinology research. As conflicting epidemiological reports have linked these bone-derived factors with multiple vascular pathologies such as atherosclerosis and calcification, there is interest in their therapeutic target potential. In order to derive any causal effects, it is important to review the basic in vitro science that has been carried out to date. Thus, this review aimed to collate studies investigating the in vitro effects of OCN, FGF23 and LCN-2 to clarify whether there is support for a basic biological or pathological role within the vasculature. Overall, the evidence base points to direct vasoactive properties of the osteokines OCN, FGF23 and LCN-2 across human and animal cells. Both OCN and FGF23 have been demonstrated to be antiapoptotic and increase eNOS phosphorylation and NO production through Akt signalling. Taken together, these findings suggest a role for these osteokines in supporting normal vascular functionality. OCN has been implicated in improving insulin signalling, and ensuing protectiveness against ER stress. OCN may be involved in calcification but further research is warranted, while there is no evidence at least of a pro-calcific effect of FGF23 in vitro. FGF23 and LCN-2 have been shown to increase proliferation in some cell types and increase and decrease ROS respectively. LCN-2 has been shown to have anti-apoptotic effects and may 
393 increase ER stress as well as have pro-inflammatory properties. LCN-2 has also been 394 demonstrated to promote angiogenesis. There is no strong evidence to suggest a pathological role 395 of OCN or FGF23 in the vasculature, however further research with LCN-2 needs to be 396 completed in order to better understand its role. Despite the topical area, a number of preliminary 397 questions remain to be answered. For example, the role of OCN and FGF-23 in inflammation, 398 the role of OCN and LCN-2 in calcification, as well as their cellular receptors and related 399 downstream signalling pathways in vascular cells. Various cleaved forms of the circulating 400 proteins should also be investigated to assess their biological activity. It is clear that further, 401 human data should be generated to understand the roles and mechanisms of actions of these 402 osteokines in physiological and pathophysiological states. 
403

404

405

406

407

408

409

410

411

412

413

414

415

416

417

418

419

420

421

422

423

424

425

426

427

428

429

430

431

432

433

434

435

436

437

438

439

440

441

442

443

444

445

446

447

448

449

450

451

452

453

References

AlVelos, M., PIMENTEL, R., PINHO, E., GOMES, A., LOURENCO, P., TELES, M. J., ALMEIDA, P., GUIMARAES, J. T. \& BETTENCOURT, P. 2011. Neutrophil gelatinase-associated lipocalin in the diagnosis of type 1 cardio-renal syndrome in the general ward. Clin $J$ Am Soc Nephrol, 6, 476-81.

AMERSFOORT, J., SCHAFTENAAR, F. H., DOUNA, H., VAN SANTBRINK, P. J., KRONER, M. J., VAN PUIJVELDE, G. H. M., QUAX, P. H. A., KUIPER, J. \& BOT, I. 2018. Lipocalin-2 contributes to experimental atherosclerosis in a stage-dependent manner. Atherosclerosis, 275, 214-224.

ANDRUKHOVA, O., SLAVIC, S., SMORODCHENKO, A., ZEITZ, U., SHALHOUB, V., LANSKE, B., POHL, E. E. \& ERBEN, R. G. 2014a. FGF23 regulates renal sodium handling and blood pressure. EMBO Mol Med, 6, 744-59.

ANDRUKHOVA, O., SMORODCHENKO, A., EGERBACHER, M., STREICHER, C., ZEITZ, U., GOETZ, R., SHALHOUB, V., MOHAMMADI, M., POHL, E. E., LANSKE, B. \& ERBEN, R. G. 2014b. FGF23 promotes renal calcium reabsorption through the TRPV5 channel. Embo j, 33, 229-46.

BELLOWS, C. G., REIMERS, S. M. \& HEERSCHE, J. N. 1999. Expression of mRNAs for type-I collagen, bone sialoprotein, osteocalcin, and osteopontin at different stages of osteoblastic differentiation and their regulation by 1,25 dihydroxyvitamin D3. Cell Tissue Res, 297, 249-59.

BINKLEY, N. C., KRUEGER, D. C., ENGELKE, J. A., FOLEY, A. L. \& SUTTIE, J. W. 2000. Vitamin $\mathrm{K}$ supplementation reduces serum concentrations of under-gammacarboxylated osteocalcin in healthy young and elderly adults. Am J Clin Nutr, 72, 1523-8.

BONEWALD, L. F. \& WACKER, M. J. 2013. FGF23 Production by Osteocytes. Pediatr Nephrol, 28, 563-8.

BONNET, N. 2017. Bone-Derived Factors: A New Gateway to Regulate Glycemia. Calcif Tissue Int, 100, 174-183.

BRANDI, M. L. \& COLLIN-OSDOBY, P. 2006. Vascular biology and the skeleton. J Bone Miner Res, 21, 183-92.

CAIRNS, J. R. \& PRICE, P. A. 1994. Direct demonstration that the vitamin K-dependent bone Gla protein is incompletely gamma-carboxylated in humans. J Bone Miner Res, 9, 1989-97.

CASTELLHEIM, A., BREKKE, O. L., ESPEVIK, T., HARBOE, M. \& MOLLNES, T. E. 2009. Innate immune responses to danger signals in systemic inflammatory response syndrome and sepsis. Scand J Immunol, 69, 479-91.

CELESTE, A. J., ROSEN, V., BUECKER, J. L., KRIZ, R., WANG, E. A. \& WOZNEY, J. M. 1986. Isolation of the human gene for bone gla protein utilizing mouse and rat CDNA clones. EMBO J, 5, 1885-90.

CHAKRABORTY, S., KAUR, S., GUHA, S. \& BATRA, S. K. 2012. The multifaceted roles of neutrophil gelatinase associated lipocalin (NGAL) in inflammation and cancer. Biochim Biophys Acta, 1826, 129-69.

CHEN, G., LIU, Y., GOETZ, R., FU, L., JAYARAMAN, S., HU, M. C., MOE, O. W., LIANG, G., LI, X. \& MOHAMMADI, M. 2018. alpha-Klotho is a non-enzymatic molecular scaffold for FGF23 hormone signalling. Nature, 553, 461-466.

CHEN, L., LI, Q., YANG, Z., YE, Z., HUANG, Y., HE, M., WEN, J., WANG, X., LU, B., HU, J., LIU, C., LING, C., QU, S. \& HU, R. 2013. Osteocalcin, glucose metabolism, lipid profile and chronic low-grade inflammation in middle-aged and elderly Chinese. Diabet Med, 30, 309-17.

CHUNG, C. P., CHANG, Y. C., DING, Y., LIM, K., LIU, Q., ZHU, L., ZHANG, W., LU, T. S., MOLOSTVOV, G., ZEHNDER, D. \& HSIAO, L. L. 2017. alpha-Klotho expression

Peer] reviewing PDF | (2019:01:34734:2:0:NEW 7 May 2019) 
454

455

456

457

458

459

460

461

462

463

464

465

466

467

468

469

470

471

472

473

474

475

476

477

478

479

480

481

482

483

484

485

486

487

488

489

490

491

492

493

494

495

496

497

498

499

500

501

502

503

504

505

506

determines nitric oxide synthesis in response to FGF-23 in human aortic endothelial cells. PLoS One, 12, e0176817.

DALAL, M., SUN, K., CAPPOLA, A. R., FERRUCCI, L., CRASTO, C., FRIED, L. P. \& SEMBA, R. D. 2011. Relationship of serum fibroblast growth factor 23 with cardiovascular disease in older community-dwelling women. Eur J Endocrinol, 165, 797-803.

DAVID, V., FRANCIS, C. \& BABITT, J. L. 2017. Ironing out the cross talk between FGF23 and inflammation. Am J Physiol Renal Physiol, 312, F1-8.

DESJARDiNS, L., LIABEUF, S., RENARD, C., LENGLET, A., LEMKE, H. D., CHOUKROUN, G., DRUEKE, T. B. \& MASSY, Z. A. 2012. FGF23 is independently associated with vascular calcification but not bone mineral density in patients at various CKD stages. Osteoporos Int, 23, 2017-25.

DEVIREDDY, L. R., TEODORO, J. G., RICHARD, F. A. \& GREEN, M. R. 2001. Induction of apoptosis by a secreted lipocalin that is transcriptionally regulated by IL-3 deprivation. Science, 293, 829-34.

DOU, J., LI, H., MA, X., ZHANG, M., FANG, Q., NIE, M., BAO, Y. \& JIA, W. 2014. Osteocalcin attenuates high fat diet-induced impairment of endothelium-dependent relaxation through Akt/eNOS-dependent pathway. Cardiovasc Diabetol, 13, 74.

DUCY, P. 2011. The role of osteocalcin in the endocrine cross-talk between bone remodelling and energy metabolism. Diabetologia, 54, 1291-7.

EILENBERG, W., STOJKOVIC, S., PIECHOTA-POLANCZYK, A., KAUN, C., RAUSCHER, S., GROGER, M., KLINGER, M., WOJTA, J., NEUMAYER, C., HUK, I. \& DEMYANETS, S. 2016. Neutrophil Gelatinase-Associated Lipocalin (NGAL) is Associated with Symptomatic Carotid Atherosclerosis and Drives Pro-inflammatory State In Vitro. Eur J Vasc Endovasc Surg, 51, 623-31.

ERBEN, R. G. 2017. Pleiotropic Actions of FGF23. Toxicol Pathol, 45, 904-10.

FERRON, M., WEI, J., YOSHIZAWA, T., DUCY, P. \& KARSENTY, G. 2010. An ELISA-based method to quantify osteocalcin carboxylation in mice. Biochem Biophys Res Commun, 397, 691-6.

FISCHER, D. C., MISCHEK, A., WOLF, S., RAHN, A., SALWESKI, B., KUNDT, G. \& HAFFNER, D. 2012. Paediatric reference values for the C-terminal fragment of fibroblast-growth factor-23, sclerostin, bone-specific alkaline phosphatase and isoform $5 \mathrm{~b}$ of tartrateresistant acid phosphatase. Ann Clin Biochem, 49, 546-53.

FLISER, D., KOLLERITS, B., NEYER, U., ANKERST, D. P., LHOTTA, K., LINGENHEL, A., RITZ, E., KRONENBERG, F., KUEN, E., KONIG, P., KRAATZ, G., MANN, J. F., MULLER, G. A., KOHLER, H. \& RIEGLER, P. 2007. Fibroblast growth factor 23 (FGF23) predicts progression of chronic kidney disease: the Mild to Moderate Kidney Disease (MMKD) Study. J Am Soc Nephrol, 18, 2600-8.

FLO, T. H., SMITH, K. D., SATO, S., RODRIGUEZ, D. J., HOLMES, M. A., STRONG, R. K., AKIRA, S. \& ADEREM, A. 2004. Lipocalin 2 mediates an innate immune response to bacterial infection by sequestrating iron. Nature, 432, 917-21.

GARNERO, P., GRIMAUX, M., SEGUIN, P. \& DELMAS, P. D. 1994. Characterization of immunoreactive forms of human osteocalcin generated in vivo and in vitro. $J$ Bone Miner Res, 9, 255-64.

GUO, Q., LI, H., XU, L., WU, S., SUN, H. \& ZHOU, B. 2017. Undercarboxylated osteocalcin reverts insulin resistance induced by endoplasmic reticulum stress in human umbilical vein endothelial cells. Sci Rep, 7, 46.

GUTIERREZ, O. M., MANNSTADT, M., ISAKOVA, T., RAUH-HAIN, J. A., TAMEZ, H., SHAH, A., SMITH, K., LEE, H., THADHANI, R., JUPPNER, H. \& WOLF, M. 2008. Fibroblast growth factor 23 and mortality among patients undergoing hemodialysis. N Engl J Med, 359, 584-92.

HAN, Y., YOU, X., XING, W., ZHANG, Z. \& ZOU, W. 2018. Paracrine and endocrine actions of bone-the functions of secretory proteins from osteoblasts, osteocytes, and osteoclasts. Bone Res, 6, 16.

Peer] reviewing PDF | (2019:01:34734:2:0:NEW 7 May 2019) 
507

508

509

510

511

512

513

514

515

516

517

518

519

520

521

522

523

524

525

526

527

528

529

530

531

532

533

534

535

536

537

538

539

540

541

542

543

544

545

546

547

548

549

550

551

552

553

554

555

556

557

558

HANNEMANN, A., FRIEDRICH, N., SPIELHAGEN, C., RETTIG, R., ITTERMANN, T., NAUCK, M. \& WALLASCHOFSKI, H. 2013. Reference intervals for serum osteocalcin concentrations in adult men and women from the study of health in Pomerania. BMC Endocr Disord, 13, 11.

HAUSCHKA, P. V., LIAN, J. B., COLE, D. E. C. \& GUNDBERG, C. M. 1989. Osteocalcin and matrix Gla protein: vitamin K-dependent proteins in bone. Physiol. Rev., 69, 9901047.

HAUSCHKA, P. V., LIAN, J. B. \& GALLOP, P. M. 1975. Direct identification of the calciumbinding amino acid, gamma-carboxyglutamate, in mineralized tissue. Proc Natl Acad Sci U S A, 72, 3925-9.

HSU, H. J. \& WU, M. S. 2009. Fibroblast growth factor 23: a possible cause of left ventricular hypertrophy in hemodialysis patients. Am J Med Sci, 337, 116-22.

IDELEVICH, A., RAIS, Y. \& MONSONEGO-ORNAN, E. 2011. Bone Gla protein increases HIF1alpha-dependent glucose metabolism and induces cartilage and vascular calcification. Arterioscler Thromb Vasc Biol, 31, e55-71.

IKI, M., TAMAKI, J., FUJITA, Y., KOUDA, K., YURA, A., KADOWAKI, E., SATO, Y., MOON, J. S., TOMIOKA, K., OKAMOTO, N. \& KURUMATANI, N. 2012. Serum undercarboxylated osteocalcin levels are inversely associated with glycemic status and insulin resistance in an elderly Japanese male population: Fujiwara-kyo Osteoporosis Risk in Men (FORMEN) Study. Osteoporos Int, 23, 761-70.

ISAKOVA, T., XIE, H., YANG, W., XIE, D., ANDERSON, A. H., SCIALLA, J., WAHL, P., GUTIERREZ, O. M., STEIGERWALT, S., HE, J., SCHWARTZ, S., LO, J., OJO, A., SONDHEIMER, J., HSU, C. Y., LASH, J., LEONARD, M., KUSEK, J. W., FELDMAN, H. I. \& WOLF, M. 2011. Fibroblast growth factor 23 and risks of mortality and end-stage renal disease in patients with chronic kidney disease. Jama, 305, 2432-9.

JUNG, C. H., LEE, W. J., HWANG, J. Y., LEE, M. J., SEOL, S. M., KIM, Y. M., LEE, Y. L. \& PARK, J. Y. 2013. The preventive effect of uncarboxylated osteocalcin against free fatty acid-induced endothelial apoptosis through the activation of phosphatidylinositol 3-kinase/Akt signaling pathway. Metabolism, 62, 1250-7.

KARSENTY, G. 2017. UPDATE ON THE BIOLOGY OF OSTEOCALCIN. Endocr Pract, 23, 12701274.

KJELDSEN, L., JOHNSEN, A. H., SENGELOV, H. \& BORREGAARD, N. 1993. Isolation and primary structure of NGAL, a novel protein associated with human neutrophil gelatinase. J Biol Chem, 268, 10425-32.

KNAPEN, M. H., HAMULYAK, K. \& VERMEER, C. 1989. The effect of vitamin K supplementation on circulating osteocalcin (bone Gla protein) and urinary calcium excretion. Ann Intern Med, 111, 1001-5.

KNAPEN, M. H., JIE, K. S., HAMULYAK, K. \& VERMEER, C. 1993. Vitamin K-induced changes in markers for osteoblast activity and urinary calcium loss. Calcif Tissue Int, 53, 815.

KONDO, A., KAWAKUBO-YASUKOCHI, T., MIZOKAMI, A., CHISHAKI, S., TAKEUCHI, H. \& HIRATA, M. 2016. Uncarboxylated Osteocalcin Increases Serum Nitric Oxide Levels and Ameliorates Hypercholesterolemia in Mice Fed an Atherogenic Diet. Electronic Journal of Biology, 13.

LARSSON, T., NISBETH, U., LJUNGGREN, O., JUPPNER, H. \& JONSSON, K. B. 2003. Circulating concentration of FGF-23 increases as renal function declines in patients with chronic kidney disease, but does not change in response to variation in phosphate intake in healthy volunteers. Kidney Int, 64, 2272-9.

LEE, A. J., HODGES, S. \& EASTELL, R. 2000. Measurement of osteocalcin. Ann Clin Biochem, 37 ( Pt 4), 432-46.

LEE, N. K., SOWA, H., HINOI, E., FERRON, M., AHN, J. D., CONFAVREUX, C., DACQUIN, R., MEE, P. J., MCKEE, M. D., JUNG, D. Y., ZHANG, Z., KIM, J. K., MAUVAIS-JARVIS, F.,

Peer) reviewing PDF | (2019:01:34734:2:0:NEW 7 May 2019) 
559

560

561

562

563

564

565

566

567

568

569

570

571

572

573

574

575

576

577

578

579

580

581

582

583

584

585

586

587

588

589

590

591

592

593

594

595

596

597

598

599

600

601

602

603

604

605

606

607

608

609

610

611
DUCY, P. \& KARSENTY, G. 2007. Endocrine regulation of energy metabolism by the skeleton. Cell, 130, 456-69.

LEE, S., KIM, J. H., SEO, J. W., HAN, H. S., LEE, W. H., MORI, K., NAKAO, K., BARASCH, J. \& SUK, K. 2011. Lipocalin-2 Is a chemokine inducer in the central nervous system: role of chemokine ligand 10 (CXCL10) in lipocalin-2-induced cell migration. J Biol Chem, 286, 43855-70.

LI, J., ZHANG, H., YANG, C., LI, Y. \& DAI, Z. 2016. An overview of osteocalcin progress. J Bone Miner Metab, 34, 367-79.

LIAO, M., HUANG, L., MAO, Y., JIANG, Y., YAO, Z., LIN, X., LU, Z., WU, C., QIN, X., ZHANG, H. \& MO, Z. 2015. Serum Osteocalcin Is Associated with Inflammatory Factors in Metabolic Syndrome: A Population-Based Study in Chinese Males. Mediators Inflamm, 2015, 683739.

LIM, K., LU, T. S., MOLOSTVOV, G., LEE, C., LAM, F. T., ZEHNDER, D. \& HSIAO, L. L. 2012. Vascular Klotho deficiency potentiates the development of human artery calcification and mediates resistance to fibroblast growth factor 23. Circulation, 125, 2243-55.

LINDBERG, K., OLAUSON, H., AMIN, R., PONNUSAMY, A., GOETZ, R., TAYLOR, R. F., MOHAMMADI, M., CANFIELD, A., KUBLICKIENE, K. \& LARSSON, T. E. 2013. Arterial klotho expression and FGF23 effects on vascular calcification and function. PLoS One, 8, e60658.

LUCEY, A. J., PASCHOS, G. K., THORSDOTTIR, I., MARTINEZ, J. A., CASHMAN, K. D. \& KIELY, M. 2013. Young overweight and obese women with lower circulating osteocalcin concentrations exhibit higher insulin resistance and concentrations of Creactive protein. Nutr Res, 33, 67-75.

LUO, Y., MA, X., PAN, X., XU, Y., XIONG, Q., XIAO, Y., BAO, Y. \& JIA, W. 2016. Serum lipocalin-2 levels are positively associated with not only total body fat but also visceral fat area in Chinese men. Medicine (Baltimore), 95, e4039.

LUUKINEN, H., KAKONEN, S. M., PETTERSSON, K., KOSKI, K., LAIPPALA, P., LOVGREN, T., KIVELA, S. L. \& VAANANEN, H. K. 2000. Strong prediction of fractures among older adults by the ratio of carboxylated to total serum osteocalcin. $J$ Bone Miner Res, 15, 2473-8.

MARTHI, A., DONOVAN, K., HAYNES, R., WHEELER, D. C., BAIGENT, C., ROONEY, C. M., LANDRAY, M. J., MOE, S. M., YANG, J., HOLLAND, L., DI GIUSEPPE, R., BOUMA-DE KRIJGER, A., MIHAYLOVA, B. \& HERRINGTON, W. G. 2018. Fibroblast Growth Factor23 and Risks of Cardiovascular and Noncardiovascular Diseases: A Meta-Analysis. J Am Soc Nephrol, 29, 2015-2027.

MILLAR, S. A., PATEL, H., ANDERSON, S. I., ENGLAND, T. J. \& O'SULLIVAN, S. E. 2017. Osteocalcin, Vascular Calcification, and Atherosclerosis: A Systematic Review and Meta-analysis. Front Endocrinol (Lausanne), 8, 183.

MIRZA, M. A., LARSSON, A., LIND, L. \& LARSSON, T. E. 2009a. Circulating fibroblast growth factor-23 is associated with vascular dysfunction in the community. Atherosclerosis, 205, 385-90.

MIRZA, M. A., LARSSON, A., MELHUS, H., LIND, L. \& LARSSON, T. E. 2009b. Serum intact FGF23 associate with left ventricular mass, hypertrophy and geometry in an elderly population. Atherosclerosis, 207, 546-51.

MISHRA, J., DENT, C., TARABISHI, R., MITSNEFES, M. M., MA, Q., KELLY, C., RUFF, S. M., ZAHEDI, K., SHAO, M., BEAN, J., MORI, K., BARASCH, J. \& DEVARAJAN, P. 2005. Neutrophil gelatinase-associated lipocalin (NGAL) as a biomarker for acute renal injury after cardiac surgery. Lancet, 365, 1231-8.

MISHRA, J., MORI, K., MA, Q., KELLY, C., BARASCH, J. \& DEVARAJAN, P. 2004. Neutrophil gelatinase-associated lipocalin: a novel early urinary biomarker for cisplatin nephrotoxicity. Am J Nephrol, 24, 307-15.

MOSIALOU, I., SHIKHEL, S., LIU, J. M., MAURIZI, A., LUO, N., HE, Z., HUANG, Y., ZONG, H., FRIEDMAN, R. A., BARASCH, J., LANZANO, P., DENG, L., LEIBEL, R. L., RUBIN,

Peer] reviewing PDF | (2019:01:34734:2:0:NEW 7 May 2019) 
612

613

614

615

616

617

618

619

620

621

622

623

624

625

626

627

628

629

630

631

632

633

634

635

636

637

638

639

640

641

642

643

644

645

646

647

648

649

650

651

652

653

654

655

656

657

658

659

660

661

662

663

664

M., NICKOLAS, T., CHUNG, W., ZELTSER, L. M., WILLIAMS, K. W., PESSIN, J. E. \& KOUSTENI, S. 2017. MC4R-dependent suppression of appetite by bone-derived lipocalin 2. Nature, 543, 385-390.

MURALI, S. K., ROSCHGER, P., ZEITZ, U., KLAUSHOFER, K., ANDRUKHOVA, O. \& ERBEN, R. G. 2016. FGF23 Regulates Bone Mineralization in a 1,25(OH)2 D3 and KlothoIndependent Manner. J Bone Miner Res, 31, 129-42.

NAKAHARA, T., KAWAI-KOWASE, K., MATSUI, H., SUNAGA, H., UTSUGI, T., ISO, T., ARAI, M., TOMONO, S. \& KURABAYASHI, M. 2016. Fibroblast growth factor 23 inhibits osteoblastic gene expression and induces osteoprotegerin in vascular smooth muscle cells. Atherosclerosis, 253, 102-110.

OURY, F., KHRIMIAN, L., DENNY, C. A., GARDIN, A., CHAMOUNI, A., GOEDEN, N., HUANG, Y. Y., LEE, H., SRINIVAS, P., GAO, X. B., SUYAMA, S., LANGER, T., MANN, J. J., HORVATH, T. L., BONNIN, A. \& KARSENTY, G. 2013. Maternal and offspring pools of osteocalcin influence brain development and functions. Cell, 155, 228-41.

OURY, F., SUMARA, G., SUMARA, O., FERRON, M., CHANG, H., SMITH, C. E., HERMO, L., SUAREZ, S., ROTH, B. L., DUCY, P. \& KARSENTY, G. 2011. Endocrine regulation of male fertility by the skeleton. Cell, 144, 796-809.

PITTAS, A. G., HARRIS, S. S., ELIADES, M., STARK, P. \& DAWSON-HUGHES, B. 2009. Association between serum osteocalcin and markers of metabolic phenotype. $J$ Clin Endocrinol Metab, 94, 827-32.

PLANTALECH, L., GUILLAUMONT, M., VERGNAUD, P., LECLERCQ, M. \& DELMAS, P. D. 1991. Impairment of gamma carboxylation of circulating osteocalcin (bone gla protein) in elderly women. J Bone Miner Res, 6, 1211-6.

PRICE, P. A., OTSUKA, A. A., POSER, J. W., KRISTAPONIS, J. \& RAMAN, N. 1976. Characterization of a gamma-carboxyglutamic acid-containing protein from bone. Proc Natl Acad Sci U S A, 73, 1447-51.

RICHTER, B. \& FAUL, C. 2018. FGF23 Actions on Target Tissues-With and Without Klotho. Front Endocrinol (Lausanne), 9.

RICHTER, B., HALLER, J., HAFFNER, D. \& LEIFHEIT-NESTLER, M. 2016. Klotho modulates FGF23-mediated NO synthesis and oxidative stress in human coronary artery endothelial cells. Pflugers Arch, 468, 1621-35.

ROOS, M., LUTZ, J., SALMHOFER, H., LUPPA, P., KNAUSS, A., BRAUN, S., MARTINOF, S., SCHOMIG, A., HEEMANN, U., KASTRATI, A. \& HAUSLEITER, J. 2008. Relation between plasma fibroblast growth factor-23, serum fetuin-A levels and coronary artery calcification evaluated by multislice computed tomography in patients with normal kidney function. Clin Endocrinol (Oxf), 68, 660-5.

SARKAR, P. D. \& CHOUDHURY, A. B. 2013. Relationships between serum osteocalcin levels versus blood glucose, insulin resistance and markers of systemic inflammation in central Indian type 2 diabetic patients. Eur Rev Med Pharmacol Sci, 17, 1631-5.

SARMENTO-DIAS, M., SANTOS-ARAUJO, C., POINHOS, R., OLIVEIRA, B., SILVA, I. S., SILVA, L. S., SOUSA, M. J., CORREIA, F. \& PESTANA, M. 2016. Fibroblast growth factor 23 is associated with left ventricular hypertrophy, not with uremic vasculopathy in peritoneal dialysis patients. Clin Nephrol, 85, 135-41.

SCIALLA, J. J., LAU, W. L., REILLY, M. P., ISAKOVA, T., YANG, H. Y., CROUTHAMEL, M. H., CHAVKIN, N. W., RAHMAN, M., WAHL, P., AMARAL, A. P., HAMANO, T., MASTER, S. R., NESSEL, L., CHAI, B., XIE, D., KALLEM, R. R., CHEN, J., LASH, J. P., KUSEK, J. W., BUDOFF, M. J., GIACHELLI, C. M. \& WOLF, M. 2013. Fibroblast growth factor 23 is not associated with and does not induce arterial calcification. Kidney Int, 83, 115968.

SEILER, S., ROGACEV, K. S., ROTH, H. J., SHAFEIN, P., EMRICH, I., NEUHAUS, S., FLOEGE, J., FLISER, D. \& HEINE, G. H. 2014. Associations of FGF-23 and sKlotho with cardiovascular outcomes among patients with CKD stages 2-4. Clin J Am SoC Nephrol, 9, 1049-58.

Peer] reviewing PDF | (2019:01:34734:2:0:NEW 7 May 2019) 
665

666

667

668

669

670

671

672

673

674

675

676

677

678

679

680

681

682

683

684

685

686

687

688

689

690

691

692

693

694

695

696

697

698

699

700

701

702

703

704

705

706

707

708

709

710

711

712

713

714

715

716

SILSWAL, N., TOUCHBERRY, C. D., DANIEL, D. R., MCCARTHY, D. L., ZHANG, S., ANDRESEN, J., STUBBS, J. R. \& WACKER, M. J. 2014. FGF23 directly impairs endothelium-dependent vasorelaxation by increasing superoxide levels and reducing nitric oxide bioavailability. Am J Physiol Endocrinol Metab.

SIX, I., OKAZAKI, H., GROSS, P., CAGNARD, J., BOUDOT, C., MAIZEL, J., DRUEKE, T. B. \& MASSY, Z. A. 2014. Direct, acute effects of Klotho and FGF23 on vascular smooth muscle and endothelium. PLoS One, 9, e93423.

SMITH, E. R. 2014. The Use of Fibroblast Growth Factor 23 Testing in Patients with Kidney Disease. Clin J Am Soc Nephrol, 9, 1283-303.

SMITH, E. R., CAI, M. M., MCMAHON, L. P. \& HOLT, S. G. 2012. Biological variability of plasma intact and C-terminal FGF23 measurements. J Clin Endocrinol Metab, 97, 3357-65.

STOHR, R., SCHUH, A., HEINE, G. H. \& BRANDENBURG, V. 2018. FGF23 in Cardiovascular Disease: Innocent Bystander or Active Mediator? Front Endocrinol (Lausanne), 9, 351.

SUGIYAMA, T. \& KAWAI, S. 2001. Carboxylation of osteocalcin may be related to bone quality: a possible mechanism of bone fracture prevention by vitamin $\mathrm{K}$. J Bone Miner Metab, 19, 146-9.

TACEY, A., QARADAKHI, T., BRENNAN-SPERANZA, T., HAYES, A., ZULLI, A. \& LEVINGER, I. 2018. Potential Role for Osteocalcin in the Development of Atherosclerosis and Blood Vessel Disease. Nutrients, 10.

TSUKAMOTO, Y., ICHISE, H., KAKUDA, H. \& YAMAGUCHI, M. 2000. Intake of fermented soybean (natto) increases circulating vitamin K2 (menaquinone-7) and gammacarboxylated osteocalcin concentration in normal individuals. J Bone Miner Metab, $18,216-22$.

URAKAWA, I., YAMAZAKI, Y., SHIMADA, T., IIJIMA, K., HASEGAWA, H., OKAWA, K., FUJITA, T., FUKUMOTO, S. \& YAMASHITA, T. 2006. Klotho converts canonical FGF receptor into a specific receptor for FGF23. Nature, 444, 770-4.

VERKAIK, M., JUNI, R. P., VAN LOON, E. P. M., VAN POELGEEST, E., KWEKKEBOOM, R. F. J., GAM, Z., RICHARDS, W. G., TER WEE, P. M., HOENDEROP, J. G. J., ERINGA, E. C. \& VERVLOET, M. G. 2018. FGF23 impairs peripheral microvascular function in renal failure. Am J Physiol Heart Circ Physiol.

WANG, G., LIU, S., WANG, L., MENG, L., CUI, C., ZHANG, H., HU, S., MA, N. \& WEI, Y. 2017. Lipocalin-2 Promotes Endoplasmic Reticulum Stress and Proliferation by Augmenting Intracellular Iron in Human Pulmonary Arterial Smooth Muscle Cells. Int J Biol Sci, 13, 135-144.

WANG, G., LIU, X., MENG, L., LIU, S., WANG, L., LI, J., CUI, C., MENG, J., HU, S. \& WEI, Y. 2014. Up-regulated lipocalin-2 in pulmonary hypertension involving in pulmonary artery SMC resistance to apoptosis. Int J Biol Sci, 10, 798-806.

WANG, G., MA, N., MENG, L., WEI, Y. \& GUI, J. 2015. Activation of the phosphatidylinositol 3-kinase/Akt pathway is involved in lipocalin-2-promoted human pulmonary artery smooth muscle cell proliferation. Mol Cell Biochem, 410, 207-13.

WANG, Y. 2012. Small lipid-binding proteins in regulating endothelial and vascular functions: focusing on adipocyte fatty acid binding protein and lipocalin-2. $\mathrm{Br} \mathrm{J}$ Pharmacol, 165, 603-21.

WANG, Y., LAM, K. S., KRAEGEN, E. W., SWEENEY, G., ZHANG, J., TSO, A. W., CHOW, W. S., WAT, N. M., XU, J. Y., HOO, R. L. \& XU, A. 2007. Lipocalin-2 is an inflammatory marker closely associated with obesity, insulin resistance, and hyperglycemia in humans. Clin Chem, 53, 34-41.

WOLF, M., KOCH, T. A. \& BREGMAN, D. B. 2013. Effects of iron deficiency anemia and its treatment on fibroblast growth factor 23 and phosphate homeostasis in women. $J$ Bone Miner Res, 28, 1793-803.

Peer) reviewing PDF | (2019:01:34734:2:0:NEW 7 May 2019) 
717

718

719

720

721

722

723

724

725

726

727

728

729

730

731

732

733

734

735
WU, L., DU, Y., LOK, J., LO, E. H. \& XING, C. 2015. Lipocalin-2 enhances angiogenesis in rat brain endothelial cells via reactive oxygen species and iron-dependent mechanisms. $J$ Neurochem, 132, 622-8.

XIAO, Y., XU, A., HUI, X., ZHOU, P., LI, X., ZHONG, H., TANG, W., HUANG, G. \& ZHOU, Z. 2013. Circulating lipocalin-2 and retinol-binding protein 4 are associated with intimamedia thickness and subclinical atherosclerosis in patients with type 2 diabetes. PLoS One, 8, e66607.

YAN, L., BORREGAARD, N., KJELDSEN, L. \& MOSES, M. A. 2001. The high molecular weight urinary matrix metalloproteinase (MMP) activity is a complex of gelatinase B/MMP-9 and neutrophil gelatinase-associated lipocalin (NGAL). Modulation of MMP-9 activity by NGAL. J Biol Chem, 276, 37258-65.

ZHOU, B., LI, H., LIU, J., XU, L., ZANG, W., WU, S. \& SUN, H. 2013. Intermittent injections of osteocalcin reverse autophagic dysfunction and endoplasmic reticulum stress resulting from diet-induced obesity in the vascular tissue via the NFkappaB-p65dependent mechanism. Cell Cycle, 12, 1901-13.

ZHU, D., MACKENZIE, N. C., MILLAN, J. L., FARQUHARSON, C. \& MACRAE, V. E. 2013. A protective role for FGF-23 in local defence against disrupted arterial wall integrity? Mol Cell Endocrinol, 372, 1-11. 


\section{Table $\mathbf{1}$ (on next page)}

Summary of studies investigating in vitro effects of osteocalcin on human and animal vascular cells

Abbreviations; OCN, osteocalcin; VECs, vascular endothelial cells; VSMCS, vascular smooth muscle cells; AECs, aortic endothelial cells; HUVECs, human umbilical vein endothelial cells; UCOCN, uncarboxylated OCN; COCN, carboxylated OCN; ER, endoplasmic reticulum; mTOR, mechanistic target of rapamycin; NFKB, Nuclear factor-KB; HIF-1 $\alpha$, hypoxia inducible factor 1 $\alpha$; PI3-K, phosphoinositide 3-kinase; eNOS, endothelial nitric oxide synthase. 
Table 1. Summary of studies investigating in vitro effects of osteocalcin on human and animal vascular cells

\begin{tabular}{|c|c|c|c|c|c|}
\hline Study & Cell type & $\begin{array}{l}\text { Type of } \\
\text { OCN }\end{array}$ & Concentration & Results & Conclusions \\
\hline Idelevich et al., 2011 & Murine VSMCs & Total OCN & Unknown & $\begin{array}{l}\text { OCN was shown to be a glucose metabolism-modulating } \\
\text { factor, through HIF-1 } \alpha \text {. }\end{array}$ & $\begin{array}{l}\text { OCN is involved in } \\
\text { glucose-metabolism }\end{array}$ \\
\hline Zhou et al., 2013 & $\begin{array}{l}\text { Murine VECs } \\
\text { and VSMCs }\end{array}$ & ucOCN & $5 \mathrm{ng} / \mathrm{mL}$ & $\begin{array}{l}\text { ucOCN protected against tunicamycin induced ER stress } \\
\text { and autophagy, and improved insulin signalling in an } \\
\text { Akt/mTOR/NFKB pathway. }\end{array}$ & $\begin{array}{l}\text { Protective effect of } \\
\text { ucOCN and improved } \\
\text { insulin signalling }\end{array}$ \\
\hline Jung et al., 2013 & Human AECs & ucOCN & $0.3-30 \mathrm{ng} / \mathrm{mL}$ & $\begin{array}{l}\text { Increased eNOS and NO, and prevented linoleic acid } \\
\text { induced apoptosis in } \mathrm{PI3}-\mathrm{K} / \mathrm{Akt} \text { dependent manner. }\end{array}$ & $\begin{array}{l}\text { Protective effect of } \\
\text { ucOCN }\end{array}$ \\
\hline Dou et al., 2014 & HUVECS & Total OCN & $10-150 \mathrm{ng} / \mathrm{mL}$ & $\begin{array}{l}>30 \mathrm{ng} / \mathrm{mL} \text { OCN increased eNOS and Akt } \\
\text { phosphorylation in a time- and dose-dependent manner. }\end{array}$ & $\begin{array}{l}\text { Potential protective } \\
\text { effect of total OCN }\end{array}$ \\
\hline Kondo et al., 2016 & Human AECs & $\begin{array}{l}\text { ucOCN } \\
\text { cOCN }\end{array}$ & $\begin{array}{l}25 \text { and } 100 \\
\mathrm{ng} / \mathrm{mL}\end{array}$ & $\begin{array}{l}\text { ucOCN increased eNOS phosphorylation after } 30 \\
\text { minutes but cOCN had no effect. }\end{array}$ & $\begin{array}{l}\text { Potential protective } \\
\text { effect of ucOCN }\end{array}$ \\
\hline Guo et al., 2017 & HUVECS & ucOCN & $5 \mathrm{ng} / \mathrm{mL}$ & $\begin{array}{l}\text { In insulin-resistant cells (induced by tunicamycin) ucOCN } \\
\text { improved insulin signal transduction via PI3-K/Akt/NFKB } \\
\text { pathways. }\end{array}$ & $\begin{array}{l}\text { ucOCN is involved in } \\
\text { insulin signalling }\end{array}$ \\
\hline
\end{tabular}

Abbreviations; OCN, osteocalcin; VECS, vascular endothelial cells; VSMCs, vascular smooth muscle cells; AECs, aortic endothelial cells; HUVECs, human umbilical vein endothelial cells; uCOCN, uncarboxylated OCN; COCN, carboxylated OCN; ER, endoplasmic reticulum; mTOR, mechanistic target of rapamycin; NFKB, Nuclear factor-KB; HIF-1 $\alpha$, hypoxia inducible factor 1- $\alpha$; PI3-K, phosphoinositide 3-kinase; eNOS, endothelial nitric oxide synthase. 


\section{Table 2 (on next page)}

Summary of studies investigating in vitro effects of FGF-23 on human and animal vascular cells

Abbreviations: FGF-23, fibroblast growth factor 23; VSMCs, vascular smooth muscle cells; AECs, aortic endothelial cells; ASMCs, aortic smooth muscle cells; HUVECs, human umbilical vein endothelial cells; OPG, osteoprotogerin; MVECs, microvascular endothelial cells; BMECs, brain microvascular endothelial cells; CAECs, coronary artery endothelial cells; FRS2 $\alpha$; FGF receptor substrate $2 \alpha ; E G R-1$, early growth response protein-1; NO, nitric oxide; ECs, endothelial cells; eNOS, endothelial nitric oxide synthase; ROS, reactive oxygen species; Nox2, NADPH oxidase 2; SOD2, superoxide dismutase 2; CAT, catalase; FGFR1, fibroblast growth factor receptor 1 . 
Table 2. Summary of studies investigating in vitro effects of FGF23 on human and animal vascular cells

\begin{tabular}{|c|c|c|c|c|c|}
\hline Study & Cell type & Context & Concentration & Results & Conclusions \\
\hline $\begin{array}{l}\text { Lim et al., } \\
2012\end{array}$ & $\begin{array}{l}\text { Human } \\
\text { ASMCs }\end{array}$ & Calcification & $5 \mathrm{ng} / \mathrm{mL}$ & $\begin{array}{l}\text { FGF23 stimulated proliferation and phosphorylation of ERK } \\
\text { and AKT in a klotho dependent fashion. Pre-treatment with } \\
\text { FGF23 and calcitriol followed by treatment with calcification } \\
\text { media inhibited development of calcification, in a klotho } \\
\text { dependent fashion. }\end{array}$ & $\begin{array}{l}\text { Vitamin D receptor activators can } \\
\text { restore Klotho expression and } \\
\text { unmask FGF23 anti-calcific } \\
\text { effects. Klotho is required for } \\
\text { vascular FGF23 signalling. }\end{array}$ \\
\hline $\begin{array}{l}\text { Zhu et al., } \\
2013\end{array}$ & $\begin{array}{l}\text { Murine } \\
\text { VSMCs }\end{array}$ & Calcification & $\begin{array}{l}10 \text { and } 50 \\
\mathrm{ng} / \mathrm{mL}\end{array}$ & $\begin{array}{l}\text { FGF23 reduced calcium deposition and increased } \\
\text { phosphorylation of ERK1/2 (but not AKT). Concomitant } \\
\text { exposure to FGF- } 23 \text { and an ERK1/2 inhibitor (PD98059; } \\
10 \mu \mathrm{M} \text { ) increased calcification. }\end{array}$ & $\begin{array}{l}\text { FGF23 signalling is likely to be a } \\
\text { protective mechanism in } \\
\text { calcification. }\end{array}$ \\
\hline $\begin{array}{l}\text { Lindberg et } \\
\text { al., } 2013\end{array}$ & $\begin{array}{l}\text { Bovine } \\
\text { VSMCs }\end{array}$ & Calcification & $\begin{array}{l}0.125-2 \\
\mathrm{ng} / \mathrm{mL}\end{array}$ & FGF23 did not modify calcification. & $\begin{array}{l}\text { No support for a role of FGF23 in } \\
\text { vascular calcification. }\end{array}$ \\
\hline $\begin{array}{l}\text { Scialla et } \\
\text { al., } 2013\end{array}$ & $\begin{array}{l}\text { Human } \\
\text { VSMCs, } \\
\text { murine } \\
\text { VSMCs }\end{array}$ & Calcification & $\begin{array}{l}1,2,10,20 \\
\text { and } 50 \mathrm{ng} / \mathrm{mL}\end{array}$ & $\begin{array}{l}\text { FGF23 had no effect on phosphate uptake or phosphate- } \\
\text { induced calcification even in the presence of soluble klotho. } \\
\text { FGF23 did not induce phosphorylation of ERK or FRS2 } \alpha \text {. }\end{array}$ & $\begin{array}{l}\text { No support for a role of FGF23 in } \\
\text { vascular calcification }\end{array}$ \\
\hline $\begin{array}{l}\text { Silswal et } \\
\text { al., } 2014\end{array}$ & $\begin{array}{l}\text { Murine } \\
\text { AECs }\end{array}$ & Normal & $9 \mathrm{ng} / \mathrm{mL}$ & $\begin{array}{l}\text { FGF23 increased superoxide levels compared with vehicle } \\
\text { which was inhibited by pre-treatment with tiron. }\end{array}$ & $\begin{array}{l}\text { FGF23 may reduce } \\
\text { vasorelaxation by decreasing NO. }\end{array}$ \\
\hline $\begin{array}{l}\text { Six et al., } \\
2014\end{array}$ & $\begin{array}{l}\text { Human } \\
\text { VSMCs, } \\
\text { HUVECs }\end{array}$ & Normal & $10 \mathrm{ng} / \mathrm{mL}$ & $\begin{array}{l}\mathrm{H}_{2} \mathrm{O}_{2} \text { concentrations increased with FGF23 and klotho in } \\
\text { HVSMCs but not in HUVECs. FGF-23 augmented } \mathrm{H}_{2} \mathrm{O}_{2} \\
\text { concentration induced by phosphate. FGF23 did not increase } \\
\text { NO production in HUVECs, but FGF23, klotho and phosphate } \\
\text { together, did. }\end{array}$ & $\begin{array}{l}\text { Klotho deficiency may be } \\
\text { deleterious as appears protective } \\
\text { against increased ROS } \\
\text { production from } \\
\text { FGF23/phosphate. }\end{array}$ \\
\hline $\begin{array}{l}\text { Nakahara } \\
\text { et al., } 2016\end{array}$ & $\begin{array}{l}\text { Human } \\
\text { ASMCs }\end{array}$ & Normal & $10 \mathrm{ng} / \mathrm{mL}$ & $\begin{array}{l}\text { FGF23 increased phosphorylated ERK, which subsequently } \\
\text { increased EGR-1 expression. }\end{array}$ & $\begin{array}{l}\text { FGF23 increased phosphorylated } \\
\text { ERK expression and EGR-1 in } \\
\text { HASMCs. }\end{array}$ \\
\hline $\begin{array}{l}\text { Richter et } \\
\text { al., } 2016\end{array}$ & $\begin{array}{l}\text { Human } \\
\text { CAECs }\end{array}$ & Normal & $10 \mathrm{ng} / \mathrm{mL}$ & $\begin{array}{l}\text { FGF23 increased activation of FGFR1. Klotho levels were } \\
\text { unaffected. FGF23 enhanced Klotho release and increased } \\
\text { levels of ADAM17. FGF23 increased NO through Akt and } \\
\text { eNOS. Cytosolic ROS increased via Nox2 and ROS } \\
\text { detoxification via SOD2 and CAT. Blocking Klotho resulted in } \\
\text { enhanced ROS formation and reduced NO availability. }\end{array}$ & $\begin{array}{l}\text { Excess FGF23 may promote } \\
\text { oxidative stress and endothelial } \\
\text { dysfunction. }\end{array}$ \\
\hline Chung et & Human & Normal & $0.5-100$ & FGF23 stimulated cell proliferation, eNOS, and NO & FGF23 promoted proliferation \\
\hline
\end{tabular}




\section{Table 3 (on next page)}

Summary of studies investigating in vitro effects of LCN-2 on human and animal vascular cells

Abbreviations: $L C N-2$, lipocalin-2; BMVECs, brain microvascular endothelial cells; BECs, brain endothelial cells; HUVECs, human umbilical vein endothelial cells; CASMCs, coronary artery smooth muscle cells; PASMCs, pulmonary artery smooth muscle cells; ROS, reactive oxygen species; IL-8, interleukin-8; IL-6, interleukin-6; MCP-1, monocyte chemoattractant protein-1; $S O D 1 / 2$, superoxide dismutase 1/2; ER, endoplasmic reticulum. 
Table 3. Summary of studies investigating in vitro effects of LCN-2 on human and animal vascular cells

\begin{tabular}{|c|c|c|c|c|}
\hline Study & Cell type & Concentration & Results & Conclusions \\
\hline Lee et al., 2011 & Rat BMVECs & $10,000 \mathrm{ng} / \mathrm{mL}$ & LCN-2 increased expression of chemokine CXCL10 & $\begin{array}{l}\text { LCN-2 may promote chemoattractants and } \\
\text { neuroinflammation }\end{array}$ \\
\hline $\begin{array}{l}\text { Wang et al., } \\
2014\end{array}$ & $\begin{array}{l}\text { Human } \\
\text { PASMCs }\end{array}$ & $\begin{array}{l}10 \mathrm{ng} / \mathrm{mL} \\
3-100 \mathrm{ng} / \mathrm{mL}\end{array}$ & $\begin{array}{l}\text { Decreased serum deprivation induced apoptosis } \\
\text { and } \mathrm{H}_{2} \mathrm{O}_{2} \text { induced apoptosis with LCN-2. LCN-2 } \\
\text { decreased the cleavage and activity of caspase-3, } \\
\text { and expression of Bax (apoptotic protein). LCN-2 } \\
\text { increased expression of SOD1/2 and decreased } \\
\text { intracellular ROS. }\end{array}$ & $\begin{array}{l}\text { LCN-2 appears protective against apoptosis and } \\
\text { decreased ROS }\end{array}$ \\
\hline Wu et al., 2015 & Rat BECs & $500-2000 \mathrm{ng} / \mathrm{mL}$ & $\begin{array}{l}\text { Enhanced Matrigel tube formation with LCN-2 } \\
\text { and migration of cells via iron and ROS related } \\
\text { pathways }\end{array}$ & LCN-2 may contribute to neurovascular recovery \\
\hline $\begin{array}{l}\text { Wang et al., } \\
2015\end{array}$ & $\begin{array}{l}\text { Human } \\
\text { PASMCs }\end{array}$ & $3-30 \mathrm{ng} / \mathrm{mL}$ & $\begin{array}{l}\text { LCN-2 increased proliferation, at least in part via } \\
\text { PI3-K signalling pathway }\end{array}$ & LCN-2 increased HPASMC proliferation \\
\hline $\begin{array}{l}\text { Eilenberg et } \\
\text { al., } 2016\end{array}$ & $\begin{array}{l}\text { HUVECs, } \\
\text { Human } \\
\text { CASMCs }\end{array}$ & $\begin{array}{l}200 \mathrm{ng} / \mathrm{mL}, 500 \\
\mathrm{ng} / \mathrm{mL} \text { or } 1000 \\
\mathrm{ng} / \mathrm{mL}\end{array}$ & $\begin{array}{l}\text { Increased secretion of inflammatory markers IL- } \\
8, \text { IL-6 and MCP-1 dose-dependently with LCN-2 }\end{array}$ & LCN-2 may be pro-inflammatory \\
\hline $\begin{array}{l}\text { Wang et al., } \\
2017\end{array}$ & $\begin{array}{l}\text { Human } \\
\text { PASMCs }\end{array}$ & $10 \mathrm{ng} / \mathrm{mL}$ & $\begin{array}{l}\text { LCN-2 increased ER stress and proliferation via } \\
\text { increased intracellular iron levels }\end{array}$ & $\begin{array}{l}\text { LCN-2 increased HPASMC proliferation and ER } \\
\text { stress }\end{array}$ \\
\hline
\end{tabular}

Abbreviations: LCN-2, lipocalin-2; BMVECs, brain microvascular endothelial cells; BECs, brain endothelial cells; HUVECs, human umbilical vein endothelial cells; CASMCS, coronary artery smooth muscle cells; PASMCs, pulmonary artery smooth muscle cells; ROS, reactive oxygen species; IL-8, interleukin-8; IL-6, interleukin6; MCP-1, monocyte chemoattractant protein-1; SOD1/2, superoxide dismutase 1/2; ER, endoplasmic reticulum. 